\title{
XXIX. Addendum to a descriptive catalogue of the minerals of the North of Ireland
}

\author{
James Bryce Jun. M.A. F.G.S.
}

To cite this article: James Bryce Jun. M.A. F.G.S. (1834) XXIX. Addendum to a descriptive catalogue of the minerals of the North of Ireland, Philosophical Magazine Series 3, 5:27, 196-198, DOI: $10.1080 / 14786443408649441$

To link to this article: http://dx.doi.org/10.1080/14786443408649441

册 Published online: 01 Jun 2009.

Submit your article to this journal $\sqsubset \pi$

Џ Article views: 3

Q View related articles $\sqsubset$ 
power of the eye itself. As soon as sufficient attention has been excited towards this curious phænomenon, I shall give the world a new discovery in this branch of optics, one so very curious that it deserves to be ushered into notice when the mind has contemplated all the preparatory steps which your knowledge shall make familiar.

It is not mere speculation when I assert that the office of the retina is to regulate the admission of light. I go on safe grounds: experiment has convinced me that the lines which compose the meshes of the retina are thicker or thinner as the opening of the pupil varies. In some future communication I will show you one of these meshes magnified. Mr. Horner is correct in saying that the eye sustains no injury in making these experiments.

The brilliancy of colouring and the kaleidoscope patterns of which Sir David Brewster speaks, belong exclusively to the peculiar shape and structure of the retina. With all the multiplied and various experiments that I have made, I have observed that all the brilliant as well as opake figures are square or angular. I have never seen anything approaching to circularity but the stars which I have described in my first paper. That star, or those stars, for there is one in the centre of each square or mesh, may be in reality composed of points or angles, but they are too minute to ascertain this fact. They scintillate.

XXIX. Addendum to a Descriptive Catalogue of the Minerals of the North of Ireland. By James Bryce, Jun., M.A., F.G.S., \&.c.

To the Editors of the Philosophical Magazine and Journal. Gentlemen,

I $N$ a note appended to a paper of mine on the minerals of the North of Ireland, published last August, you inquire, in relation to a new mineral, which Dr. Thomson has named hydrocarbonate of lime and magnesia, "Whether this mineral is allied to that which the late Mr. W. Phillips, at the suggestion of Mr. Brayley, described under the appellation of Hydrocarbonate of Lime, in the last edition (1823) of his Elementary Introduction to Mineralogy, p. 161." It is then added, from a communication by Mr. Brayley, that the latter mineral " is the result of the action of the trap dykes of the Giants' Causeway upon the chalk which they have intersected, and, according to the analysis of the late $\mathrm{Dr}$. Da Costa, would appear to be composed of four atoms carbonate of lime and there atoms water," \&c. In reply I may observe, that I believe the minerals to be distinct, though obviously closely al- 
lied. That analysed by $\mathrm{Da}$ Costa occurs wherever the trap dykes cut the chalk*. Dr. M.Donnell, who first noticed this mineral, informs me, that it was pronounced to be dolomite by several skilful mineralogists and chemists to whom he showed it at various times. The analysis of $\mathrm{Da}$ Costa, however, gave no magnesia. The other mineral yielded to Dr. Thomson some portion of that earth. It has been found only at Downhill in Derry, in veins and irregular masses in an amygdaloid of a loose texture, accompanied by zeolites and the common carbonate of lime. On these grounds I think the two minerals may be regarded is distinct; an analysis of the magnesian one will most probably be given in full in the work on mineralogy for some time expected from the pen of the distinguished chemist just named. In the System of Professor Mohs, and the excellent "Manual," by Robert Allan, Esq., just published, this and several others, usually described as distinct, are classed under calcareous spart.

It was stated in the "Catalogue," that the large crystals of quartz so frequent at Dungiven were found in a trap rock. I believe this is inaccurate. Some of the crystals are found in the bed of the river Roe, which is partly primitive; others are found in the debris of mountains of the basaltic range, but have most probably been transported thither by currents from the primitive country to the west. Small crystals of quartz, however, are frequent in our trap rocks. Hydrolite and levyne have been recently found in other places within the basaltic district besides Island Magee, and anhydrous disilicate of iron in dykes and loose boulders of trap near Larne. Mr. M'Adam suggests that it ought to have been mentioned in the "Catalogue," as a remarkable circumstance, that the magnetic or octahedral iron ore found by him in the Isle of Muck, occurs only on the external surface of the rock.

The researches of Lieut. James, R.E., in the county of Down, and the zealous labours of Mr. Patrick Doran in all

* It perhaps ought to be observed, that this mineral may have been found in the vicinity of the Causeway, but certainly not immediately there; because there is no chalk at the Causeway, nor, so far as I am aware, at any place in the trap district where columnar basalt exists. In such a case that rock rests on lias or sandstone.

$+[$ We are obliged to Mr. Bryce for his reply to our inquiry. We do not know what edition of Prof. Mohs's System he may refer to, but in Haidinger's 'Translation neither of the minerals in question is adverted to, either by name or by implication; nor would it be in accordance, we think, with Prof. Mohs's principles of classification, to include them "under calcareous spar": the other minerals "usually described as distinct" but which are also regarded by that mineralogist as varieties of calcareous spar, consist, essentially, like that mineral, of carbonate of lime alone, and are also connected with it into one species by gradual transitions of external character, or by what in Zoology and Botany is termed affinity.-E. W. B.] 
parts of the country, have added some new and very interesting minerals to our former catalogue. The following is a list of these :

Variolite. - This variety of compact felspar has been lately met with in the hornblende rock of Morne.

Anthracite.-A compact variety of this mineral, with a highly metallic lustre, occurs frequently in the grauwacké of Down.

White Carbonate of Lead-acconspanies galena and the green phosphate of lead in the Newtonard's lead-mine, Down.

Colophonite.-This mineral occurs in quartz veins traversing siliceous slate near Glassdrummond, Morre. It is of a brownish yellow colour, and is crystallized in rhombic dodecahedrons, with very unequal angles, and having striæ parallel to the lesser axis of the rhomboid. The mineral has very much the appearance of cinnamon stone.

Sulphuret of Molybdena. - This mineral has been lately discovered in a siliceous slate, or, I believe, rather a chlorite slate, on the shore near the mountains of Morne. The crystalline form is a six-sided table, terminated by a low six-sided pyramid, of which the base angles are truncated. Neither this mineral nor the colophonite have, so far as I know, been before noticed in Ireland.

Belfast, Aug. 11, 1834. Your's, \&c.

JAMES BRYCE, Jun.

XXX. On the Development of certain Trigonometrical Functions. By J. R. Young, Professor of Mathematics in the Royal College, Belfast.*

THE series given by analytical writers for the development of a circular arc in terms of its sine, cosine, and tangent are as follows:

$$
\begin{aligned}
& \sin ^{-1} x=x+\frac{x^{3}}{1.2 .3}+\frac{3^{2} x^{5}}{1.2 \cdot 3 \cdot 4.5}+, 8 \mathrm{c} . \\
& \cos ^{-1} x=\frac{\pi}{2}-x+\frac{x^{3}}{1.2 .3}-\frac{3 x^{5}}{1.2 .3 .4 .5}+, 8 \mathrm{c} . \\
& \tan ^{-1} x=x-\frac{x^{3}}{3}+\frac{x^{5}}{5}-\frac{x}{7}+, 8 \mathrm{c} .
\end{aligned}
$$

which series, as well as those for the development of the arc in terms of the other trigonometrical lines, are true only for the least of the arcs to which these trigonometrical lines be long. I am not aware that any explanation has ever been given of this want of generality; or that any one has made known how it comes to pass, that while the developments of

* Communicated by the Author. 